\title{
MANAJEMEN SUMBER DAYA BUDAYA SEBAGAI DASAR PENGEMBANGAN PARIWISATA DI MALUKU
}

\author{
Marlon NR Ririmasse
}

\section{Abstrak}

Bulan Agustus 2007 Balai Arkeologi Ambon kembali mengadakan Pameran dan Diskusi Arkeologi Tabunan. Sebagaimana tabun sebelumnya, kegiatan ini dipusatkan di Kota Ambon, dan mengambil tema Pengelolaan Sumber Daya Budaya untuk Pengembangan Pariwisata Berbasis Kearifan Lokal. Makalah ini ditulis sebagai bagian kegiatan diskusi, yang bertujuan menciptakan ruang untuk menampung pemikiran lintas instansi di Maluku, yang diharapkan dapat didayagunakan untuk menciptakan suatu iklim pengelolaan sumber daya budaya, yang mampu memberi kontribusi signifikan bagi pengembangan pariwisata di Maluku.

\section{Judulnya Pariwisata: Peluang Klasik yang Terus Berkembang dan Berubah}

Menyimak iklan pariwisata negara tetangga kita, Malaysia, di televisi nasional seakan menyadarkan bahwa ada perubahan besar dalam dunia pariwisata di negara ini. Tampil sebagai sebuah iklan, pesan-pesan pariwisata dengan durasi lumayan tersebut tentu merupakan wahana promosi. Pesannya jelas, kunjungi Malaysia, Trully Asia. Hal yang menarik dari fenomena ini adalah kenyataan bahwa iklaniklan tersebut ditampilkan di televisi nasional Indonesia. Artinya, Indonesia dipandang sebagai pasar yang harus dikelola dan dijaring untuk kepentingan pertumbuhan pariwisata Malaysia. Malaysia memang bukan satusatunya negara tetangga kita yang gencar mempromosikan potensi pariwisatanya untuk pasar Indonesia. Singapura dan India juga sudah dan cukup gencar melakukannya. Pertanyaan yang kemudian muncul adalah apa iya, orang-orang Indonesia (dalam jumlah besar) sudah cukup 
mampu untuk melakukan perjalanan wisata ke luar negeri? Sedemikian mampu sehingga dianggap potensial untuk secara khusus dikelola sebagai satu segmen pasar? Bagi yang pernah mengunjungi Singapura, akan segera menjawab pertanyaan tersebut sebagai basi. Sudah umum diketahui dalam dekade terakhir orang Indonesia lalu-lalang Singapura-Malaysia ibarat berkunjung ke rumah tetangga sebelah. Thailand, sekarang juga menjadi salah satu tujuan utama lain pelancong-pelancong dari negeri kita. Berbagai Iklan tour ke negeri-negeri tetangga ini ditawarkan dengan biaya yang terjangkau untuk sebagian besar masyarakat berpenghasilan menengah. Padahal jika mau disimak nuansa 'luar negeri' nya mungkin tidak terlalu berbeda dengan kondisi Indonesia. Namun apapun alasannya, Indonesia telah menjadi pasar yang berlomba-lomba dibidik oleh negara-negara Asean.

Pertanyaan lanjutan yang kemudian muncul adalah why? Mengapa Indonesia dipandang sebagai pasar potensial. Sebenarnya kerangka promosi yang digunakan oleh Malaysia, Singapura, atau India bukan membidik pasar Indonesia saja. Indonesia merupakan bagian dari segmen pasar regional, sesama negara di Asean dan Asia, yang sengaja dikelola secara khusus. Alasannya jelas, 80 persen pasar pariwisata dunia adalah wisatawan regional atau lokal yang datang dengan kendaraan darat atau menyeberang selatselat kecil (Kasali, 2008). Potensi pasar ini sengaja dikelola secara khusus bukan hanya karena kedekatan fisik, namun juga karena lidah dan kebiasaan hidupnya tidak berbeda secara ekstrem. Hasilnya? 80 persen wisatawan manca negara di Malaysia dan Thailand, berasal dari Indonesia, Singapura, Cina, dan India. Jika angka kunjungan wisatawan manca negara di Malaysia pada tahun 2006 meningkat dari 16,4 juta menjadi 17,5 juta serta meningkat dari 11,5 juta menjadi 13,9 juta di Thailand, maka Indonesia turut memberi kontribusi yang besar bagi pengembangan pariwisata di kedua negara ini. Data-data ini seakan menjadi ironi, jika kita menyimak jumlah wisman ke Indonesia pada tahun 2006 yang turun dari 5 juta menjadi 4,8 juta wisman. Saat kita turut memberi kontribusi bagi pertumbuhan luar biasa pariwisata negara-negara tetangga, pariwisata kita justru stagnan dan menurun.

Secara umum industri pariwisata dunia memang menunjukan tren kenaikan dalam tiga dekade terakhir. Kunjungan internasional di seluruh dunia pada tahun 1970 mencapai angka 165 juta dengan jumlah penerimaan 18 milyar dolar. Tahun 1990 angka ini meningkat menjadi
457 juta kunjungan dengan peningkatan luar biasa untuk total penerimaan menjadi 268 Milyar dolar. Tahun 2006, angka ini berlipat menjadi 846 juta kunjungan dengan pemasukan 733 milyar dolar AS. Termasuk dalam angka ini adalah 75 negara yang panorama dan kebudayaannya tidak begitu penting, namun berhasil meraup minimal satu miliar dolar AS dari sektor pariwisata. Mengacu pada tren ini, industri pariwisata diperkirakan masih akan terus tumbuh di masa depan. Data World Tourism Organization (WTO) memperkirakan kunjungan internasional akan meningkat menjadi 1,406 milyar orang pada 2010 dan 1,602 milyar orang pada tahun 2020. Dengan angka kunjungan ini diperkirakan pada tahun 2020 jumlah penerimaan dari sektor pariwisata mencapai 2 triliun dolar AS (Cecep dan Baskoro, 2007). Mengacu pada data-data ini, pariwisata kemudian diakui sebagai salah satu industri yang terbesar saat ini, dengan mengacu juga pada jumlah orang yang terlibat, pendapatan devisa, penyerapan tenaga kerja, dan kesempatan berusaha (Naisbitt, 1995; Sutardjo dan Pitana, 2007).

Melihat data-data yang cukup fantastis di atas menimbulkan pertanyaan, lantas di mana posisi Indonesia? Dengan pendapatan 4,4 milyar dolar AS pada tahun 2002, Indonesia baru mendapat porsi sekitar 0,95 persen dari total pengeluaran wisatawan dunia pada tahun yang sama (474 milyar dolar AS). Diharapkan melalui berbagai pembenahan yang telah dan terus dilaksanakan, pada tahun 2010 kunjungan wisatawan manca negara ke Indonesia bisa mencapai angka 10 juta orang dengan perolehan devisa mencapai 10 milyar dolar AS. Sampai dengan tahun 2004, pariwisata telah menjadi penyumbang devisa nomor dua terbesar bagi negara setelah migas.

Data-data di atas menunjukan industri pariwisata sangat menjanjikan sebagai sumber penerimaan nasional di masa depan. Industri ini jika dikelola dengan baik, bisa lebih prospektif dibanding sektor pertambangan yang berdampak kerusakan lingkungan. Industri pariwisata juga mampu menampung pekerja dengan spektrum yang amat luas mencakup transportasi, perhotelan, telekomunikasi, hiburan, pendidikan, makanan, cinderamata, hingga perdagangan. Mengamati Malaysia yang sangat berhasil mengembangkan pariwisata menjadi sumber pendapatan utama negara, rasanya wajar jika kita memiliki harapan yang sama. Apalagi didukung panorama dan kekayaan budaya yang jauh lebih melimpah. Atas dasar itulah, banyak pihak menyambut baik ditetapkannya Visit Indonesia Year 
2008 oleh pemerintah, setelah terakhir dilaksanakan pada 17 tahun lalu (1991). Bagaimanapun, pariwisata meliputi aspek yang sangat luas mencakup lingkungan hidup, nilai-nilai sosial, investasi, dan keamanan. Sehingga rasanya kita belum bisa terlalu berharap banyak untuk mencapai hasil maksimal, jika masalah keamanan, keselamatan penerbangan, kerusakan lingkungan, banjir dan berbagai kendala lain masih mewarnai keseharian pengelolaan negara.

\section{Halo Maluku?}

Setelah menyimak data-data di atas, wajar kiranya jika kita bertanya, lantas dimana posisi Maluku? Data terbaru yang disajikan Dinas Pariwisata menunjukan angka kunjungan wisatawan manca negara ke Maluku pada tahun 2005 adalah 2.142 orang, dengan rata-rata kenaikan antara tahun 20032005 adalah 36\%. Jika dibandingkan dengan data 4,8 juta wisman secara nasional pada tahun 2006, maka Maluku baru mendapat porsi 0,1 persen dari total wisatawan manca negara di Indonesia. Demikian halnya dengan wisatawan nusantara. Jumlah wisatawan nusantara pada tahun 2005 di Maluku adalah 18.645 orang, untuk total nasional 112,7 juta wisnus. Artinya, jumlah wisatawan nusantara yang mengunjungi Maluku hanya 0,0016 persen dari total kunjungan wisnus nasional. Bercermin pada data-data ini rasanya sudah cukup untuk menjadi barometer dimana posisi Maluku dalam industri pariwisata nasional.

Kondisi ini erat kaitannya dengan konflik sosial yang pernah melanda Maluku antara tahun 1999-2002. Dampak konflik ini terasa di semua aspek kehidupan baik masyarakat Maluku maupun bagi citra Indonesia sendiri. Citra wilayah (bekas) konflik masih cukup melekat di Maluku sampai 2004. Seiring dengan kondisi keamanan yang makin (sangat) stabil, dan pembenahan infrastruktur pasca kerusuhan telah mulai menampakan hasil yang nyata, Maluku saat ini telah memiliki wajah baru yang kembali cantik. Pembenahan dan perbaikan memang masih harus dilakukan, namun citra wilayah konflik itu sendiri agaknya telah sirna dari masyarakat Maluku. Bagi mereka yang datang dalam tiga tahun terakhir di Maluku, melihat kehidupan masyarakat yang begitu normal, agaknya akan cukup sangsi jika di wilayah ini pernah terjadi konflik. Meski demikian, citra itu nampaknya belum sepenuhnya hilang dalam lingkup nasional dan internasional. Sehingga sangat mempengaruhi angka kunjungan wisatawan ke Maluku. Namun, jika berkaca pada kondisi Maluku lima tahun lalu, angka-angka ini bisa menjadi awal yang baik. Tinggal bagaimana sekarang mempertahankan kondisi daerah yang stabil sambil membuat perencanaan pariwisata ke depan yang efektif dan efisien untuk diimplementasikan. Beberapa pokok pikiran akan dicoba untuk dikemukan sebagai sumbangan untuk mengembangkan pariwisata di Maluku.

\section{Mengembangkan Pariwisata Maluku: Apa sih yang kita punya?}

Kalau mendengar komentar umum, rasanya tidak asing pernyataanpernyataan yang membanggakan keindahan wilayah Maluku. Entah pantainya, hutannya, maupun keragamaan hayati yang dapat dinikmati. Menyimak gambaran yang disajikan Dinas Pariwisata Maluku (2007) kita akan menemukan fenomena yang sama. Dalam paparannya, Dinas Pariwisata Maluku mengkategorikan potensi pariwisata di Maluku dalam tiga segmen yaitu: wisata alam, wisata budaya, dan wisata sejarah. Komposisi ketiga segmen ini jika ditinjau dari jumlah objek wisata adalah: wisata alam 63,8 persen, wisata sejarah 34,3 persen, wisata budaya 1,8 persen. Artinya, wisata alam yang menjadi andalan utama dalam komposisi objek wisata di Maluku. Menyimak kondisi geografis Maluku yang berciri kepulauan, wajar kiranya jika panorama bahari menjadi tulang punggung citra pariwisata Maluku. Baik berupa pantai, taman laut, atau pulau-pulau kecil. Namun, jika citra panorama yang menjadi andalan, apakah citra itu sudah cukup menarik untuk mendatangkan wisatawan ke Maluku? Dalam hal ini rasa-rasanya kita harus jujur bahwa, jika berkaca pada angka kunjungan, nilai jual panorama di Maluku belum cukup laris di pasar pariwisata. Faktor yang menyebabkan hal ini memang kompleks, mulai dari masalah keamanan, manajemen, fasilitas, akses, hingga promosi. Namun setidaknya ada dua hal yang agaknya selama ini dilupakan yaitu: Pertama, penetapan tema wisata yang sesuai dengan karakter dan potensi wilayah. Kedua, pemilihan destinasi utama dalam wisata panorama sebagai Ikon pariwisata Maluku. Hal ini penting karena, keberadaan tema dan Ikon yang selaras sangatlah berperan dalam membentuk citra Maluku di pasar pariwisata nasional dan internasional. Keunikan apa dari kekayaan alam Maluku yang dapat ditawarkan pada 
wisatawan? Dan itu harus mampu diwakili oleh objek tertentu sebagai ikon yang memiliki nilai jual. Kenyataan menunjukan persepsi kita berasosiasi dengan hal-hal yang cenderung dikenal secara umum. Termasuk dalam dunia pariwisata. Sebagai contoh, ketika orang menyebut Sumatera Utara, orang akan langsung teringat pada Danau Toba, sebagai ikon pariwisata alam Sumatera Utara. Atau ketika orang menyebut Bali, maka pemikiran orang akan teringat pada Pantai Kuta, yang telah berkembang jauh lebih kompleks dari sekedar objek wisata alam. Jawa Timur, akan selalu mengingatkan kita tentang eksotisme matahari terbit di Gunung Bromo. Sama halnya dengan Sulawesi Utara. Meski wilayah baharinya tidak seluas Maluku, namun citra Bunaken sebagai taman laut internasional sangat membantu pertumbuhan pariwisata di Sulawesi Utara. Nah, di antara sekian banyak potensi panorama alam tersebut, mana yang akan kita pilih sebagai ikon pariwisata Maluku? Image Branding ini penting untuk membangun citra pariwisata yang khas di pasar.

Menyimak komposisi tema objek wisata di Maluku menarik juga untuk melihat bahwa wisata sejarah dan wisata budaya masing-masing memiliki prosentase jumlah objek 34,3 persen dan 1,8 persen. Artinya, objek-objek wisata dengan latar sejarah dan arkeologis dipandang potensial sebagai tujuan wisata di kawasan ini. Romantisme masa lalu memang menarik sekiranya bisa dikemas secara baik. Asosiasi sejarah Maluku yang lekat dengan romantisme kepulauan rempah-rempah sesungguhnya merupakan sebuah tema wisata menarik yang potensial untuk dikembangkan. Apalagi di Maluku banyak terdapat benteng-benteng Eropa yang tersebar merata di wilayah ini. Yang agak mengherankan, prosentase objek wisata budaya (tradisional) di Maluku justru sangat minim. Hanya 1,8 persen. Padahal menyimak keragaman budaya masyarakat Maluku, rasanya lebih wajar jika prosentasenya jauh di atas itu. Angka-angka ini, dapat menjadi petunjuk gambaran besar strategi pariwisata Maluku yang masih berorientasi pada wisata alam.

Memang, baik tema wisata alam, wisata sejarah, atau wisata budaya, sama-sama memiliki nilai jual tersendiri. Tinggal bagaimana dikemas sebagai objek wisata yang menarik. Namun, ada baiknya jika kita merenung sejenak, menganalisa apa yang membuat daerah-daerah kunjungan utama di Indonesia, seperti Bali, Yogyakarta, dan Toraja begitu diminati wisatawan?
Ternyata bila ditelaah lebih mendalam, minat wisatawan yang begitu besar untuk mengunjungi wilayah-wilayah ini adalah karena adanya keinginan untuk menikmati sesuatu yang tidak ditemui di tempat asalnya (Rukendi, 2006; Sektiadi, 2005). Jika hanya keindahan alam, rasanya itu bisa dinikmati di belahan dunia manapun, tanpa perlu berwisata dalam jarak yang jauh. Sehingga pengalaman berbeda tersebut biasanya bisa dialami melalui wisata budaya. Pengalaman budaya yang unik inilah yang dengan sangat berhasil, telah dikemas dan ditawarkan daerah-daerah seperti Bali, Yogyakarta, dan Toraja (Sektiadi, Ibid).

\section{Mengelola Sumber Daya Budaya: Menemukan keunikan, Membangun Citra}

Keberhasilan Bali, Yogyakarta, atau Toraja, dalam menjadi destinasi utama kelas dunia dengan keunikan budayanya, sesungguhnya merupakan keberhasilan pengelolaan ragam pusaka budaya yang memiliki ciri khas etnisitas yang kuat. Ciri etnisitas yang masih 'asli' dan 'tradisional' ini menampilkan suatu citra eksotis yang sangat menjual dalam industri pariwisata. Melalui citra eksotis ini wisatawan asing dapat menikmati penjelajahan, petualangan, dan penemuan baru. Hal ini berkaitan dengan latar belakang wisatawan yang umumnya berasal dari negara-negara yang lebih 'mapan' dan dalam kesehariannya lekat dengan kemajuan teknologi. Sehingga berwisata dalam eksotisme budaya yang masih 'asli' dan 'tradisional' dirasakan memberi pengalaman yang berbeda. Eksotisme dan keunikan budaya, menjadi faktor nilai tambah (bahkan bisa menjadi faktor utama) bagi wisatawan dalam mengunjungi suatu wilayah.

Sekarang, adakah eksotisme budaya dengan nilai keunikan tinggi yang dapat disajikan industri pariwisata Maluku? Jawabannya pasti ada. Namun seberapa unik, khas, terkenal, dan penting eksotisme budaya tersebut sehingga cukup menarik untuk mendatangkan wisatawan? Ciri pembeda dan kekhasan apa yang dimiliki untuk 'bersaing' dengan daerah-daerah lain yang juga memiliki keunikan budaya? Well, di sinilah manajemen sumber daya budaya dapat memainkan perannya.

Sumber daya budaya, termasuk di dalamnya sumber daya arkeologi, memiliki cakupan luas. Mencakup aspek gagasan, tindakan dan ketrampilan, budaya bendawi, dan saujana budaya. Dalam kajian arkeologi, Model 
manajemen sumber daya yang dikembangkan pada dasarnya merupakan buah kesadaran para arkeolog bahwa data arkeologi bersifat tak terbaharukan, terbatas, dan kontekstual. Dalam pandangan ini, sederhananya, data arkeologi ditinjau sebagai sumber daya yang sangat mungkin 'habis' dan musnah di masa depan. Untuk itu diperlukan suatu model guna melestarikan dan mengelola sumber daya ini agar dapat dimanfaatkan dalam waktu yang selama mungkin (Mc Kinsey, 1977; Tanudirdjo, 2004). Selama lebih dari empat dekade, konsep manajemen sumber daya arkeologi terus berkembang dan diperbaharui, makin kaya dan disesuaikan dengan tantangan jamannya. Jika pada awalnya model pengelolaan sumber daya arkeologi lebih ditujukan untuk tujuan pelestarian semata, dan menekankan pada aspek pengetahuan, sejarah, dan pendidikan, maka pada tahun-tahun belakangan dimensi pengelolaannya makin berkembang. Cakupan tujuan pengelolaan sumber daya arkeologi telah merambah aspek pemanfaatan untuk tujuan non arkeologis. Termasuk dalam aspek ini adalah pendidikan (umum), jati diri, politis, dan ekonomis (pariwisata). Meluasnya dimensi tujuan pengelolaan sumber daya arkeologi ini tidak lepas dari keinginan kalangan arkeologi untuk memberi manfaat yang sebesar-besarnya dari kajian arkeologi bagi kepentingan masyarakat.

Kesadaran bahwa masyarakatlah pemilik sesungguhnya dari sumber daya budaya, telah menciptakan paradigma baru dalam arkeologi yang lebih berorientasi pada publik. Sehingga, sering manajemen sumber daya arkeologi disebut sebagai arkeologi publik. Dari sini bisa ditarik kesimpulan bahwa manajemen sumber daya arkeologi pada dasarnya bertujuan agar data arkeologi dapat memberi manfaatnya yang sebesar mungkin dengan spektrum yang seluas mungkin, dan selestari mungkin. Dalam konteks inilah rasanya pengelolaan sumber daya budaya juga harus dilaksanakan, yaitu agar sumber daya tersebut mampu memberi manfaat secara maksimal, merangkul berbagai kepentingan, dan lestari dalam perubahan jaman( Mc Gimsey dan Davids, 1977; Schifer dan Gummerman, 1977; Fowler, 1982 ; Cleere, 1990, Renfrew dan Bahn, 1991; Tanudirdjo, 2004).

Model pengelolaan sumber daya budaya dalam arkeologi didasarkan pada setidaknya tiga prinsip dasar yaitu: pertama, jika ingin mengambil manfaat dari sumber daya budaya tersebut, kita harus melestarikannya.
Kedua, untuk dapat memahami manfaat apa yang dapat kita peroleh, kita harus mempelajari sumber daya tersebut. Ketiga, pengetahuan itu hanya dapat mencapai manfaatnya yang maksimal, jika diterjemahkan untuk masyarakat.

Implementasi dari prinsip dasar ini kemudian dinyatakan dalam cara kerja manajemen sumber daya arkeologi yang mencakup: Identifikasi

2. Pendugaan nilai penting

3. Pendugaan dampak

4. Mitigasi

Pada tahap identifikasi, sumber daya arkeologi di kenali menurut sifat fisik dan konteksnya. Pada tahap ini juga diidentifikasi keadaan yang berkaitan dengan potensi dan hambatan yang dapat muncul dalam proses manajemen.Proses kedua pendugaan nilai penting, merupakan cara untuk mengetahui mengapa sehingga suatu sumber daya perlu dilestarikan, serta menemukan nilai-nilai penting apa saja yang dikandungnya. Proses ketiga, pendugaan dampak, bertujuan untuk, mengidentifikasi dampak yang akan terjadi pada sumber daya arkeologi, dampak sosial pada masyarakat, serta dampak pada lingkungan. Tahap ke empat adalah mitigasi atau rancangan pengelolaan. Proses ini bertujuan untuk meredam dan mencegah penurunan nilai penting sumber daya budaya melalui pelestarian. Dalam proses ini juga disusun rekomendasi kebijakan pelestarian termasuk pemanfaatan dan penanggulangan dampak akibat pemanfaatannya.

Model pengelolaan sumber daya arkeologi ini sangat mungkin diterapkan dalam pengelolaan sumber daya budaya secara umum, serta pengelolaan sumber daya pariwisata. Tahapan-tahapan kegiatan dalam model pengelolaan sumber daya budaya di atas setidaknya cukup relevan untuk wilayah Maluku yang kaya potensi namun (masih) terbatas anggaran dan sumber daya manusia. Inti dari keseluruhan proses ini sesungguhnya adalah studi kelayakan dan identifikasi untuk menemukan potensi dan hambatan pada suatu sumber daya budaya. Dari sana bisa ditentukan kelayakan dan skala prioritas, untuk kemudian dikembangkan dengan strategi manajemen yang secara kontinyu dimonitor.

Melalui manajemen sumber daya budaya, diharapkan pengembangan model dan strategi pariwisata dapat didesain menurut karakter, potensi, dan aset alam dan budaya yang dimiliki daerah. 


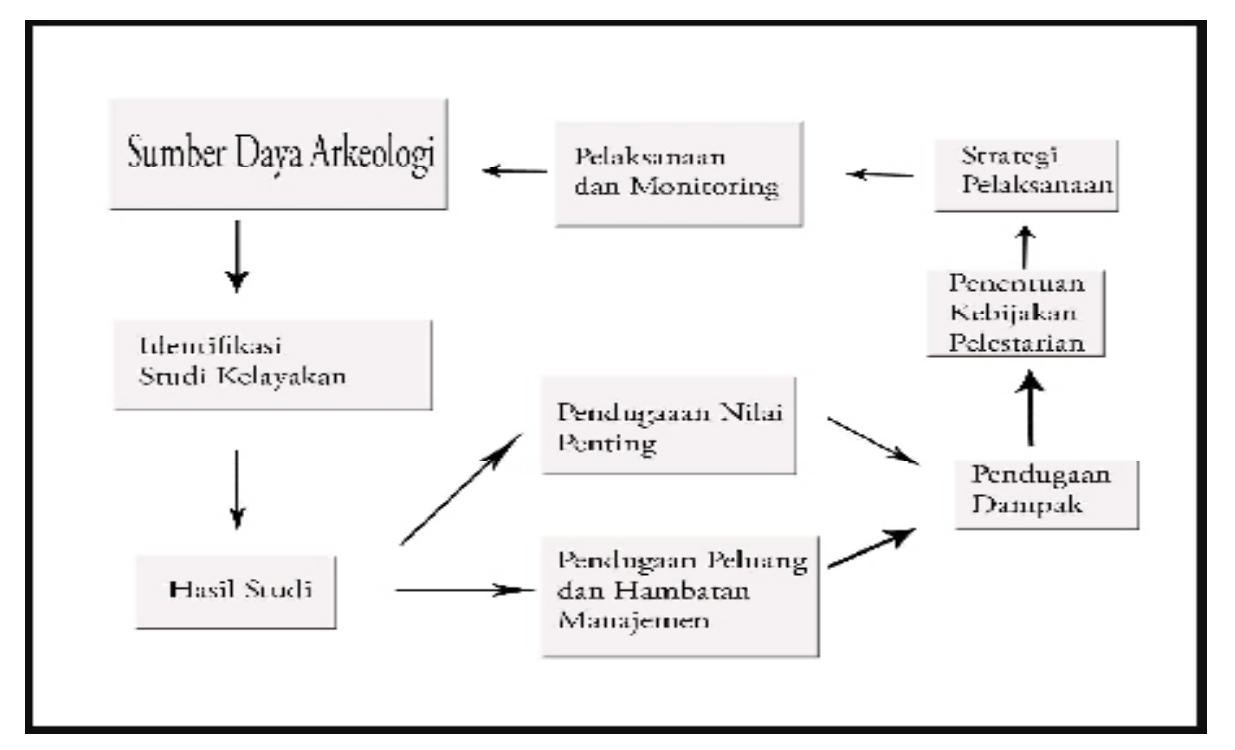

Gambar 1. Bagan Alir Cara Kerja MSA (Sumber: Tanudirjo, 2006)

Pemahaman tiga elemen ini akan membuat kita lebih mampu memetakan potensi pariwisata daerah dengan lebih akurat. Sehingga pengembangan ke depan diharapkan menjadi lebih efektif dan tepat sasaran. Pertanyaanya, bagaimana karakter, potensi, dan aset yang Maluku masih miliki saat ini?

Setidaknya ada tiga kata kunci yang dapat diacu untuk menggambarkan karakter Maluku sebagai destinasi wisata yaitu, bahari dan alam, keragaman budaya tradisional, dan sejarah. Profil geografis Maluku sebagai wilayah kepulauan dengan dominasi wilayah laut, adalah potensi besar untuk

pengembangan pariwisata berbasis bahari. Kedekatan orang-orang Maluku dengan laut tidak perlu ditanyakan lagi. Bahkan pengalaman sejarah menunjukan betapa masyarakat di wilayah ini, begitu dimanja dengan aneka sumber daya lautnya. Keindahan pantai serta panorama bawah laut di Maluku, mungkin menawarkan begitu banyak pilihan dibanding tempat manapun di Indonesia. Namun, hingga saat ini, Maluku belum mampu tampil sebagai ikon wisata bahari di Indonesia.

Ciri unik geografis berupa kepulauan dengan lebih dari seribu pulau besar kecil ini membentuk suatu ciri demografis yang juga sangat khas. Dimana karakter budaya Maluku menjadi begitu beragam antar satu wilayah dengan wilayah lainnya, satu pulau dengan pulau lainnya. Keragaman budaya ini juga merupakan potensi yang memberi lebih banyak pilihan bagi kemungkinan pengembangan wisata budaya ke depan.

Ketiga, citra sejarah Maluku sebagai the spice island, Kepulauan Rempah-Rempah, menawarkan suatu pengalaman wisata bernuansa sejarah yang berbeda, sekiranya dikelola dengan benar. Keberadaan bentengbenteng era kolonial, bisa menjadi wisata romantisme masa pelayaran dan penjelajahan yang memiliki nuansa tersendiri.

Ketiga 'tema' ini selalu ada di berbagai wilayah Maluku. Keindahan panorama, keunikan budaya tradisional, dan situs-situs sejarah, secara alami menyatu di Ambon, Lease, Seram, Banda, Buru, Kei, hingga Tanimbar. Tentu, dengan catatan derajat (kuantitas dan kualitas) suatu tema dengan tema lainnya bisa sangat berbeda antar wilayah. Di Ambon dan Lease, wisata sejarah bisa menjadi sangat menonjol karena banyaknya sebaran benteng kolonial. Di Seram, wisata budaya tradisional dan alam yang lebih menonjol. Keberadaan Taman Nasional Manusela, dengan komunitaskomunitas tradisionalnya (Naulu) yang masih hidup di desa tradisional, adalah perpaduan sempurna untuk menciptakan karakter unik Pulau Seram. Kepulauan Kei, adalah perpaduan sempurna antara wisata bahari pulau-pantai, dan keunikan budaya tradisionalnya. Keindahan pantai di Kepulauan ini dengan hamparan pasirnya, sukar untuk ditandingi wilayah lain kepulauan ini. Keberadaan masyarakat yang masih melestarikan kehidupan tradisionalnya dengan desa tradisional yang khas seperti Tanimbar Kei dan Banda Eli, adalah ikon-ikon wisata tradisi yang sangat potensial. Wilayah lain, Banda, telah menjadi kawasan yang 'unik' karena nilai sejarahnya dan panorama bawah lautnnya. Wilayah ini memang memiliki nuansa tersendiri, utamanya karena citra kota masa lalu yang dibentuk oleh bangunan-bangunan kolonial. Romantisme masa lalu Banda, dilengkapi oleh panorama bawah lautnya yang indah. Saat ini Banda Neira sementara dalam proses menuju world heritage.

Mengingat kondisi geografis Maluku sebagai wilayah kepulauan, sulit untuk menafikan faktor ini dalam pengembangan pariwisata Maluku. Koordinasi yang baik dan jaringan transportasi yang lancar menjadi satu keharusan. Namun itu memerlukan biaya yang tidak sedikit. Untuk itu, 
dalam proses ini kiranya lebih bijak jika kita bersikap realistis. Artinya, pengembangan suatu kawasan hendaknya disesuaikan dengan kondisi wilayah, sumber daya manusia, dan anggaran. Jika kondisi anggaran dan sumber daya masih jauh dari memadai, lebih baik kita berfokus pada objek-objek yang potensial dan relatif mudah dikembangkan. Untuk tahap awal, dengan mempertimbangkan infrastruktur, rasanya bisa di mulai dari kawasan Pulau Ambon terlebih dahulu, sebagai 'pilot project'. Sembari mengamati kinerja perkembangan 'kawasan percontohan' ini, kita bisa mulai mengembangkan kemungkinan skenario pengembangan kawasankawasan lain. Rekam kerja model pengelolaan yang diterapkan di kawasan Pulau Ambon, akan dimonitor dan ditinjau kembali untuk disempurnakan sebelum di terapkan pada kawasan lain. Demikian pula penting untuk menyelaraskan antara harapan dan kenyataan, artinya pasar yang menjadi sasaran harus sesuai dengan daya dukung industri pariwisata kita di Maluku. Rasanya tidak lucu jika berharap wisatawan kelas dunia dalam jumlah besar membanjiri objek-objek wisata budaya yang pengelolaannya dan fasilitas pendukungnya masih berkelas 'kabupaten'. Yang bahkan untuk bersaing di level propinsi dan nasional pun masih sukar.

Melalui pendekatan model ini diharapkan, lebih mudah bagi kita untuk mengidentifikasi objek-objek wisata budaya yang memiliki ciri khas (keunikan) yang paling unggul, serta ditinjau dari berbagai aspek pendukung paling potensial untuk dikemas dan dijual. Menemukan ciri khas adalah penting, mengingat faktor keunikan inilah yang menjadi pembeda dan daya tarik. Keunikan yang dikelola dengan baik, akan meningkatkan daya tarik objek, sehingga menjadi sesuatu yang 'harus dilihat' dan dikunjungi. Saat diskusi tahun lalu saya telah mengingatkan, bahwa sumber daya budaya yang terkelola dengan baik, lebih mudah untuk dikemas dan ditawarkan sebagai paket wisata. Sehingga penting saat ini untuk segera membenahi cara kita mengelola sumber daya budaya di Maluku, jika ingin menyelamatkan aset budaya dan mengembangkannya dalam industri wisata.

Demikian Kiranya perlu dipahami juga, bahwa mengembangkan pariwisata sebagai suatu industri bukanlah pekerjaan membalik telapak tangan, karena sifatnya yang sangat kompleks. Namun melalui rancangan pengelolaan yang tepat, sangat mungkin bagi wilayah kaya potensi seperti Maluku untuk berkembang. Sehingga keindahan dan keunikan itu bukan hanya sekedar citra pada brosur yang kadang semu dan menipu, namun hendaknya memiliki kenyataan yang jauh melebihi promosi foto dan gambar. Kesan yang baik dan pengalaman yang unik adalah media promosi yang paling ampuh. Dan untuk mencapai itu, tidak lain hanya bisa dicapai dengan menyajikan keunikan melalui sumber daya budaya yang terkelola secara profesional.

\section{Cermin: Manajemen 'Manajer' Sumber Daya Budaya Sebagai Prioritas}

Perubahan pada dasarnya hanya bisa terlaksana melalui pembenahan aktivitas manajemen dalam mengelola sumber daya. Dalam kasus sumber daya budaya untuk pariwisata, diperlukan kemampuan untuk menyelaraskan berbagai sumber daya yang ada meliputi : aset budaya (cultural resources), anggaran (money), sumber daya manusia (buman resources), fasilitas (facility), dan informasi (information). Di atas semuanya, satu sumber daya yang jauh lebih penting karena tidak pernah terbarukan adalah, waktu (time). Sigap tidaknya kita dalam mengelola sumber daya budaya yang kita miliki, akan menentukan kiprah kita dalam industri pariwisata dalam waktu yang terus berjalan. Dan sekiranya diharuskan memilih aspek mana yang lebih dulu harus dikelola, rasanya jauh lebih penting jika kita mendahulukan pembenahan para 'manajer' sumber daya budaya. Artinya, pembenahan aspek sumber daya manusia harus menjadi prioritas. Adalah manusia dan kemampuannya mengambil keputusan yang menentukan bagaimana sumber daya budaya untuk pariwisata tersebut akan dikelola dan menggerakan roda sistem pengelolaannya. "Perubahan pada dasarnya bukanlah menerapkan teknologi, metode, struktur, atau manajer-manajer baru. Perubahan pada dasarnya adalah mengubah cara manusia dalam berpikir dan berperilaku”' (Kasali, 2007). 


\section{DAFTAR PUSTAKA}

Anonim. Paparan Dinas Pariwisata Maluku dalam Pameran dan Diskusi Arkeologi 2007.

Cleere, Henry F. 1990. Introduction: the rationale of archaeological management, dalam Henry F. Cleere (ed), Archaeological heritage management in the modern world. London: Unwin-Hyman.

Fowler, D. 1982. Cultural Resource Management, dalam M.B. Schiffer (ed,) Advances in archaeological method and theory, vol. 2. New York : Academic Press.

Kasali, Renald. 2007. Re-Code Your Change DNA. Jakarta. Gramedia Pustaka Utama

Kasali, Renald. 2008. Visit Indonesia Banjir 2008, dalam Kompas 16 Februari, 2008

McGimsey, C. dan H. Davis (eds). 1977. The management of archaeological resource, the Airlie House Report. Special Publication of the Society for American Archaeology.

Rukendi, Cecep. 2006. Menemukan Kembali Konsep Pariwisata Budaya Indonesia, dalam Jurnal Kepariwisataan Indonesia Vol. 1 No. 12006. Jakarta. Departemen Kebudayaan dan Pariwisata.

Rukendi, Cecep, dan Baskoro, Bra. 2007. Pembangunan Pariwisata Berbasis Aset dalam Rangka Memerangi Kemiskinan di Indonesia, dalam Jurnal Kepariwisataan Indonesia Vol. 2 No. 1 Maret 2007. Jakarta. Departemen Kebudayaan dan Pariwisata.

Schiffer, M. B. and G.J. Gummerman (ed). 1977. Conservation Archaeology. New York : Academic Press.

Sektiadi. 2005. Pengelolaan Sumber Daya Arkeologi Menghadapi
Globalisasi, Meraba Agenda, dalam Atmosudiro, Sumijati (Ed.), Potret Transformasi Budaya di Era Global. Yogyakarta. Sub Unit Penerbitan Unit Pengkajian dan Pengembangan Fakultas Ilmu Budaya Universitas Gadjah Mada.

Sutarjo dan Pitana, I.G. 2007. Beberapa Konsideran dalam Pengembangan Pariwisata Daerah (Studi Kasus Kabupaten Kutai Kerta Negara) dalam Jurnal Kepariwisataan Indoneisa Vol. 2 No. 1 Maret 2007. Jakarta. Departemen Kebudayaan dan Pariwisata.

Tanudirdjo, Daud Aris. 2004. Pengelolaan Sumber Daya Arkeologi: Sebuah Pengantar, disampaikan dalam Workshop Pengelolaan Sumber Daya Arkeologi 2004. Sangiran.

2006. Pengantar Pengelolaan Manajemen Sumber Daya Budaya. Disampaikan dalam Workshop Pengelolaan Sumber Daya Arkeologi 2006. Yogyakarta. 